\title{
摩䂶による水酸化マグネシウムのメカノケミカル変化 ${ }^{1)}$
}

\author{
(1971 年 10 月 23 日受理)
}

\author{
荒井康夫・安江任・三宅久利*
}

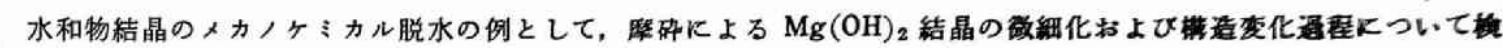

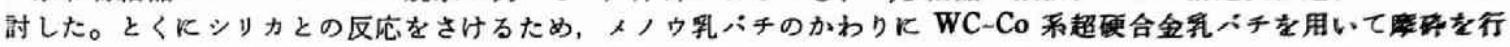
なった。

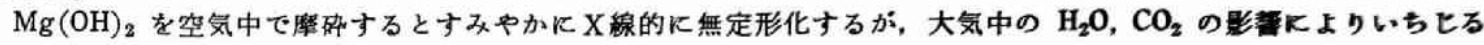
しく增量する。その DTA 曲線は $4 \mathrm{MgCO}_{3} \cdot \mathrm{Mg}(\mathrm{OH})_{2} \cdot 4 \mathrm{H}_{2} \mathrm{O}$ の組成として報ぜられている塩基性炭酸マグネシウム のそれとよく類似している。空気中ょり $\mathrm{H}_{2} \mathrm{O}, \mathrm{CO}_{2}$ をとりのぞいて摩础を行なってる無定形化するが, その重影变化 からはメカノケミカル脱水は認められない。その DTA 曲線に阽ける特推は, $\mathbf{M g}(\mathbf{O H})_{2}$ の分解後引きつついて起こ

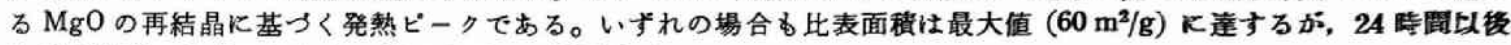
《 2 次粒子の生成によりその值はしだいに低下する。

$10^{-2} \mathrm{mmHg}$ 程度の真空中で摩砕すると, $\mathrm{Mg}(\mathrm{OH})_{2}$ のすみやかな無定形化ととるにょカノケミカル䯟本の結景とし

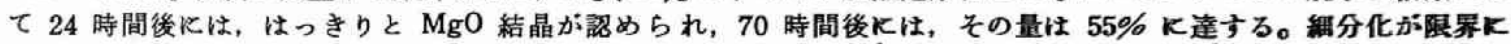
近つくととすに不整化, 膨張化した $\mathrm{MgO}$ 結晶（格子定数 $4.2368 \AA$, 結晶子の大きさ $100 \AA$ A $)$ は無定形 $\mathbf{M g}(\mathbf{O H})_{2}$ とメカノケミカル平衡に達する。この場合, 空気中摩砾物とくらて比表面磧はいちしるしく增大する（70 時閵後に は $200 \mathrm{~m}^{2} / \mathrm{g}$ )。摩破物の表面活性を塩基性点の数から討議した。

\section{1 腥言}

水和物結晶の機械的破壊にあたっては水分子を多く含む面がも っとも切断されやすく、この面からメカノケミカル脱水の発生が 期待される。著者らはすでに $\mathrm{CaSO}_{4} \cdot 2 \mathrm{H}_{2} \mathrm{O}$ を例として, 摩砕に よる構造内の $\mathrm{H}_{2} \mathrm{O}$ 分子の脱出 ${ }^{2)}, \mathrm{Ca}\left(\mathrm{H}_{2} \mathrm{PO}_{4}\right)_{2} \cdot \mathrm{H}_{2} \mathrm{O}$ および $\mathrm{CaHPO}_{4} \cdot 2 \mathrm{H}_{2} \mathrm{O}$ を例として水素結合の破壞による脱水縮合 ${ }^{3) 4}$ に ついて報告を行なってきた。本報では引きつつきき水和物結晶のメ カノヶミカル脱水の例として, $\mathrm{Mg}(\mathrm{OH})_{2}$ を対象として OH 基の 举動について検討したので報告する。

$\mathrm{Mg}(\mathrm{OH})_{2}$ 結晶の機械的破壊については，すでに Gregg らは 振怔ボールミルによる粉砕を 700 時間以上おこない, $\mathrm{CdI}_{2}$ 型層 状権造をとる $\mathrm{Mg}(\mathrm{OH})_{2}$ はズリ応力によって層間が容易に分断さ れ，(001）面の分猏倠と再結合とが無秩序に行なわれると述べ，格 子不整や㒶間吸着水の增大を報告していろが5)，振動ボールミル によって格子を破壊し、脱水や転移を起こさせることはをずかし いと絬論している6)。しかし，Gregg らの実験は平均粒径が $1 \mu$ 程度と比較的大きい上に, 破壊により生成する活性 $\mathrm{Mg}(\mathrm{OH})_{2}$ と その環境との相互関係については明らかにしていない。

著者らはメノウ乳バチ内摩碎による $\mathrm{Mg}(\mathrm{OH})_{\mathbf{2}}$ 結晶の破壊を吕 気, メタノール、ペンゼン, 四塩化炭素などの各種媒体中におい、 て行ない, 粒径 $0.5 \mu$ 程度の敬細化に成功したが, 大気中の $\mathrm{H}_{2} \mathrm{O}, \mathrm{CO}_{2}$ の影整， メノウ乳ぐチを䧿成する $\mathrm{SiO}_{2}$ との反応をさ けることがでさず, $\mathrm{Mg}(\mathrm{OH})_{2}$ のメカノケミカル分解を論誐する

1）この報文を“水酸化物のメカノケミカル变化火咸する研究 (第 1 叙)”とする.

* 日本大学理工学部工業化学科, 東京都千代田区神田駿河台

2) 荒井康夫, 安江 任, 工化, $73,2603(1970)$.

3）荒井康夫，青木然樹，工化，71，1407(1968).

4) 䫧井康夫, 安江 低, 工化, 74, 1343(1971).

5) S. J.Gregg, J.P. Saenz, J. Appl.Chem., 16,300(1966).

6) S.J.Gregg, Chem. \& Ind., 11, 611(1968).
ことができなかっだ。そこで，本報では大気中の $\mathrm{H}_{2} \mathrm{O}, \mathrm{CO}_{2}$ の

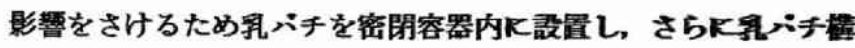
成物貿との反応をさけるため WC-Co 系超硕合金冐バチを地用 し、さきの報告の問題点を解消して実験を行なったので, 以下K 報告する。

\section{2 試料むよび実験方法}

\section{1 試 料}

供試水酸化マグネシウム $\mathrm{Mg}(\mathrm{OH})_{2}$ 江関東化学式会社悬の度 印特級試薬で，同社による分析結果をつぎにす。

\begin{tabular}{|c|c|c|c|}
\hline $\begin{array}{l}\mathrm{Cl}^{-} \\
\mathrm{SO}^{8-}\end{array}$ & $0.0015 \%$ & 硝 酸 程 & $0.25 \%$ \\
\hline $\mathrm{CO}_{3}^{2}{ }^{2-}$ & 限度内合格 & 強熱减量 & $30.96 \%$ \\
\hline $\mathrm{Pb}$ & $0.001 \%$ & 希䣫酸溶状 & 唀 明 \\
\hline $\mathrm{Fe}$ & $0.0003 \%$ & & \\
\hline
\end{tabular}

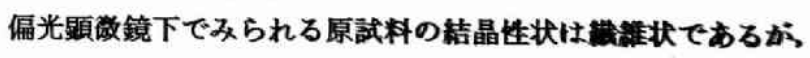

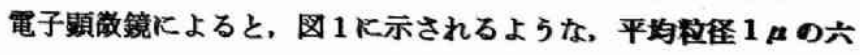

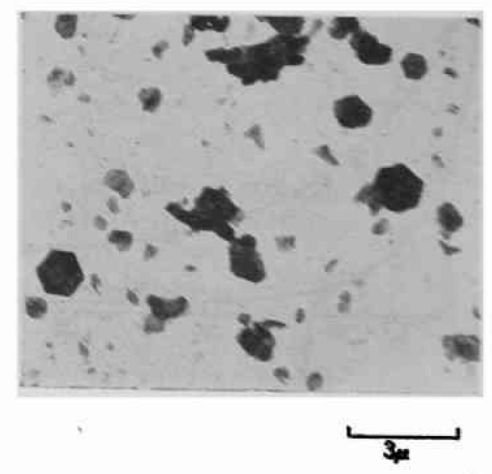

Fig. 1 Electron microscopic observation of original $\mathrm{Mg}(\mathrm{OH})_{\text {a }}$

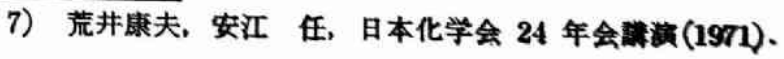


角板状結晶の集合体として観察され，X線回折によるとこれらの 結晶は $\mathrm{Mg}(\mathrm{OH})_{2}$ で, 結晶子の大きさは (001) 面で $400 \AA$ 程度で あることが確かめられた。

\section{2 超硬合金乳バチと真空摩砕機}

塩基性である $\mathrm{Mg}(\mathrm{OH})_{2}$ 粉末をメノウ乳バチ中で摩砕すると, 乳 バチを構成する酸性酸化物 $\mathrm{SiO}_{2}$ との間に反応が起こり，乳パチ 摩碎面のいらじるしい摩耗をるたらす。このよらな障害を防ぐた め, 本報では超硬合金製の乳棒, 乳バチによって構成される侏式 会社石川工場特製の真空摩砕機を使用した。すなわち, 自動回転 式乳棒 ( $\phi 40 \mathrm{~mm}, 50 \mathrm{rpm}, 1$ 本) と乳活 $(\phi 140 \mathrm{~mm} \times 30 \mathrm{~mm})$ を密閉容器内に拉き，そのパルブにロータリーポンブを接続し排 気すると, 内部は $2 \times 10^{-2} \mathrm{mmHg}$ 程度の真空度（木下式回転 MacLeod 真空計使用) を保持することができるし，また各種の ガスを導入することによって任意の摩砕雾囲気をつくることが可 能である。摩确機を図 2 に示す。

超硬合金とよばれる材料は一般に WC を主成分として Co で 暁結した合金で耐摩耗性，耐食性のいちじるしいことから近年注 目されている8 。本報で用いた超硬合金は関西超硬合金株式会社 によって製造され，その組成は WC $94.3 \%$, Co $5.7 \%$ からな り，密度は $15.1 \mathrm{~g} / \mathrm{cm}^{3}$, 硬度は Vickers 硬さ (Hv) で 1550〜 $1650 \mathrm{~kg} / \mathrm{mm}^{2}$ である。文献 $\mathrm{mm}^{2}$, コランダムで $2127 \mathrm{~kg} / \mathrm{mm}^{2}$ である。また, 他の文献 ${ }^{10)} に$ よれば新らしいMohrs 硬さで $\mathrm{Al}_{2} \mathrm{O}_{3}$, WC はいずれも 12 で示 されるという。これらの文献から超硬合金はメノウないしサファ

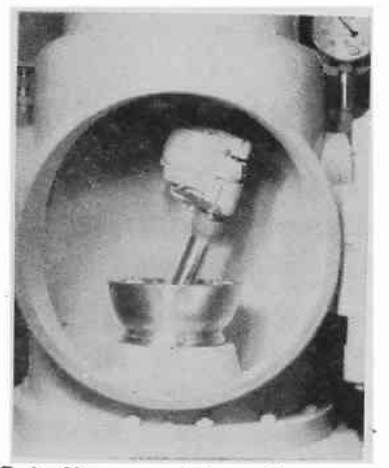

Fig. 2 Grinding machine of vacuum type

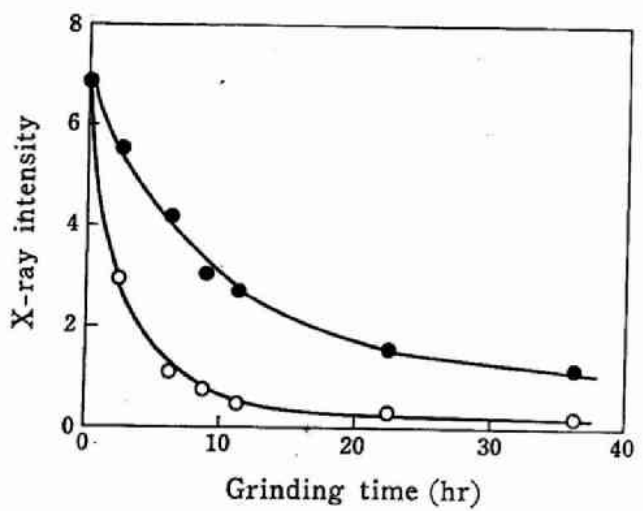

Fig. 3 Grinding effect with mortar materials O : Agate mortar, : WC-Co system mortar

8）安藤茂生, 化学々工業, 24，410(1971).

9）日本釷物学会編，“実験鉱物学”，共立出版(1966) p. 237.

10）今井宏, セラミックス，3，946(1968).

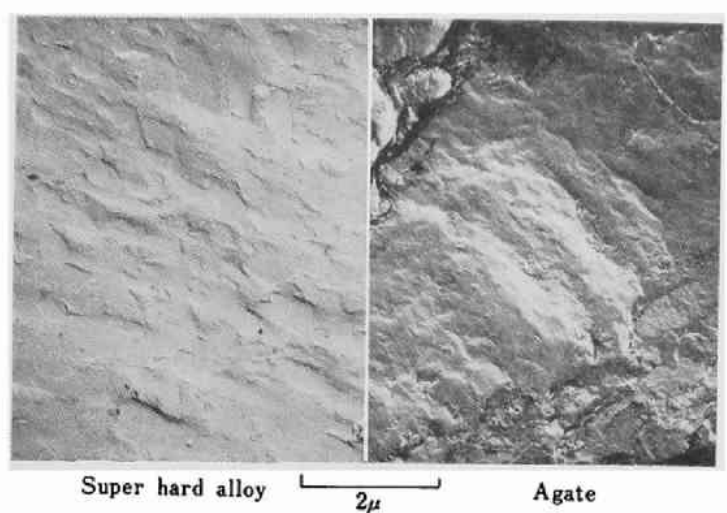

Fig. 4 Electron microscopic observation of the grinding surface of mortars (2 stages replica method)

イアに匹敵する硬さを有することがらかがえう。

実際に石英粉末を試料として, 超硬合金乳バチとメノウ乳バチ の摩砕効果を, 無定形化にともなら X線回折ピークの強度変化て 比較してみると図 3 のとおりとなる。すなわち、WC-Co 系合金 乳バチの摩砕効果は, メノウ乳パチのそれにくらぺるとややまと るが，摩砕時間の延長により同じ効果に達することができる。

WC-Co 系合金の大ぎ特徽は耐食性で, $37 \% \mathrm{HCl}, 50 \% \mathrm{NaOH}$ に対する 24 時間後の重量減はそれぞれ $60,0.3 \mathrm{~g} / \mathrm{m}^{2}$ である。 $\mathrm{Mg}(\mathrm{OH})_{2}$ 粉末を試料として 1000 時間以上の摩砕に供した乳・ チ表面の摩砕状況を電子顕微鏡で観察したのが図4 である。メノ ウ乳バチの侵食ははなはたしいが，超硬合金乳バチの摩砕面は平 滑で，金属的光沢をまったく失わない。

\section{3 実験方法}

$\mathrm{Mg}(\mathrm{OH})_{2}$ 試料を上記摩确機によって摩砕するにあたり, 試料 採取量は摩砕後の諸実験に必要な最小量と摩砕効果の大きい条件 とを考慮しながら $500 \mathrm{mg}$ を標準とさだめた。摩砕は原則として 常温で行なったが, 密閉容器内で長時間摩砕を行ならと, 摩碎面 に护摩摖熱の発生のために, 乳バチ内面の温度は $40^{\circ} \mathrm{C}$, 容 器内温度は $30 \sim 32^{\circ} \mathrm{C}$ 澾する。摩砕雲囲気は, (1) 空気中, (2) $\mathrm{H}_{2} \mathrm{O}, \mathrm{CO}_{2}$ を取りのぞいた空気中，(3) 真空中の 3 種類と し，(1）については大気開放，（2）については $40 \% \mathrm{KOH}$ 溶 液, conc $\mathrm{H}_{2} \mathrm{SO}_{4}$ 溶液を通過させ, $\mathrm{CO}_{2}$ および $\mathrm{H}_{2} \mathrm{O}$ をとりのぞい た空気を減圧された密閉容器内に導入し, 減圧排出, 導入の操作 をくり返し最終的に $1 \mathrm{~atm}$ とした。（3）については摩碀中ロー タリーポンプを作動して容器内の真空度をつねに $2 \times 10^{-2} \mathrm{mmHg}$ に保持した。

試料は所定時間摩砕したのら，ただらにデシタータ（㖕燥剤シ リカゲル）中に括き内部を真空にして保持し，できるかきりすみ やかに測定に供した。まず, 結晶の細分化の程度を BET 法によ る比表面積変化から求め, 破壊にともなら構造変化はX線回折, 示差熱分析, 熱重量分析, 赤外吸収スペクトルにより㭘討した が，使用した装置および測定方法は既報2)とまったく同じである ので,ここでは省略する。たたし通常の BET 法においては, 試 料の $100^{\circ} \mathrm{C}$ 加熱による脱気処理を必要とするが，本報においては 加熱による摩砕物の再結晶を防止するために，2 時間の真空脱気 $\left(10^{-1} \mathrm{mmHg}\right)$ とよった。また, 結晶の微細化, 格子の破壊の程 度をX線回折ピークの半価幅から結晶子の大きさおよび格子不整 として求めた ${ }^{11)}$ 。摩砕物の形状, 粒径, 表面の観察にあたって 11）荒井康夫, 安江 任, 工化, 72, 1980(1969). 
は，超音波発生装置により周波数 $28.4 \mathrm{kHz}$, 出力 $125 \mathrm{~W}$ の高閣 波を発生させ、これをメタノール中で試料にあてて十分に分散さ せたのち，日本電子株式会社製電子顕故鏡 JEM 50 B, JEM $100 \mathrm{U}$ および併用走查像䘽察装搕を用いて撮影を行なった。

固体塩基表面の活生については，とくにその触媒としての選択 性に関連して注目されている。固体表面の塩基強度は吸着した酸 をその共役塩基に変える表面の能力であり，すなわち，吸着酸に 電子対を与える表面の能力である。このような塩基性点の構造に ついては諸説があり，構造不整に基つく疍荷のかたよりによるる ので，無定形化による格子のひずみ，表面の $\mathrm{OH}$ 基と $\mathrm{O}^{2-}$ イオ

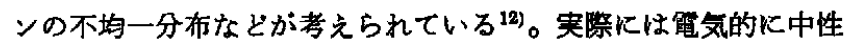
な酸指示薬（ $p K_{a}=9.3$ フェールフタレイン, $p K_{a}=7.1$ ブロ モチモールブルー）を無極性溶媒中で固体塩基表面に吸着させ, その変色により識別する方法がとられている ${ }^{13)}$ 。本報であ摩砕物 の表面活性を求める手段として指示薬法により塩基性点の強度を 湘定した。方法の概要を述べると，摩砕終了後の試料約 $100 \mathrm{mg}$ をすばやく秤畐したのち、ベンゼン $10 \mathrm{ml}$ のはいった三角フラス コ内にいれ，超音波を 30 秒かけて分散させる。これに酸指示薬 フェノールフタレインベンゼン溶液の上澄液（フェノールフタレ インはベンゼンに難溶) を加え，これを $0.01 \mathrm{~mol} / \mathrm{l}$ 安息香酸べ ンゼン溶液で滴定し，赩から無色になった点をるって終点と し，その滴定值より単位 $\mathrm{g}$ あたの $\mathrm{mmol}$ 数で塩基量をあらわ す。完全に復色しない終点を決定するだめに滴定所要時間は 2 時 間を必要とする。

\section{3 実験結果および考察}

\section{1 空気中拜砕}

$\mathrm{Mg}(\mathrm{OH})_{2}$ 結晶の摩碎化よる細分化過程は，まずX線回折図形 の傿定形化によって観察される。図 5 は $\mathrm{H}_{2} \mathrm{O}, \mathrm{CO}_{2}$ をとりのぞい た空気中に拈ける $\mathrm{Mg}(\mathrm{OH})_{2}$ 摩㸴物の X線回折図形の変化を 15 $55^{\circ}(2 \theta)$ の範囲で示した日ので，測定条件は target CuK $K_{\alpha}, 30$ $\mathrm{kV}, 10 \mathrm{~mA}$, 入射条件 div. slit $1^{\circ}$, rec. slit $0.2 \mathrm{~mm}$, scale factor 16, mult. 1, time const. 1 , 走查条件 $1^{\circ} 2 \theta / \mathrm{min}, 4+1$ 速 度 $2 \mathrm{~cm} / \mathrm{min}$ である。

図 5 Kよれば $\mathrm{Mg}(\mathrm{OH})_{2}$ 結晶は摩砕によりしだい破壤され， 58 時間後には回折ピークはまったく消えてX線的に無定形状態 となる。無定形化の場合, 結晶子の大きさの測定限度は約 $100 \AA$ であるからい)，この程度以下に細分化されたといえよう。 $\mathrm{H}_{2} \mathrm{O}$, $\mathrm{CO}_{2}$ をとりのぞかないで大気開放下で摩挽を行なった場合すX線 回折図形の変化は図 5 とほとんど変わらないが，無定形化速度は ややすみやかで 20 時間後には完全に無定形化する。しかし，微 細化, 表面積增加にとるないその活性表面に吸着ないし反応する $\mathrm{H}_{2} \mathrm{O}, \mathrm{CO}_{2}$ の影響は無視できない。

開放大気中摩砕物の示差熱分析曲線（昇温速度 $8^{\circ} \mathrm{C} / \mathrm{min}$, 以下 DTA 曲線という)は図6のとおりで, その特徽は室谷ら ${ }^{15)} に よ$ って報告されている $4 \mathrm{MgCO}_{3} \cdot \mathrm{Mg}(\mathrm{OH})_{2} \cdot 4 \mathrm{H}_{2} \mathrm{O}$ の組成からなる 塩基性炭酸マグネシウムのそれによく一致している。たたし， $4 \mathrm{H}_{2} \mathrm{O}$ の脱水に対応する約 $330^{\circ} \mathrm{C}$ の吸熟ビークが消隇している。

12) J.B.Peri, J. Phys.Chem., 69, 211(1965).

13) 田部浩三, 化学工業, 19, 18(1968).

14) R.C. Rau, Norelco Reptr., 10, 114(1963).

15）宾谷 筧, 城野勝博, 後藤忠俊, 工化, 71, 1972(1968).
塩基性炭酸マグネシウムを $400^{\circ} \mathrm{C} に$ 加熱すると脱水と同時に一度 無定形化するが，摩碀物はこれと同じようにょカノケミカル瞣水 によって無定形化した㙁基性炭酸マグネシウムとみなすことがで きる。したがって, 空気中摩碎においては $\mathrm{H}_{2} \mathrm{O}, \mathrm{CO}_{2}$ の影第のた

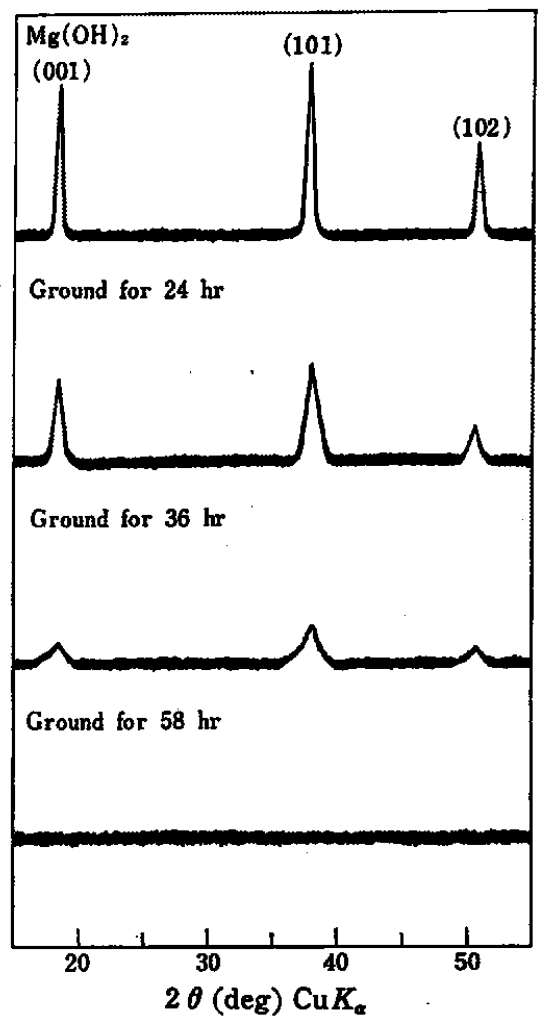

Fig. $5 \mathrm{X}$-ray diffraction patterns of $\mathrm{Mg}(\mathrm{OH})_{2}$, ground in the air (removed $\mathrm{H}_{2} \mathrm{O}$ and $\mathrm{CO}_{2}$ )

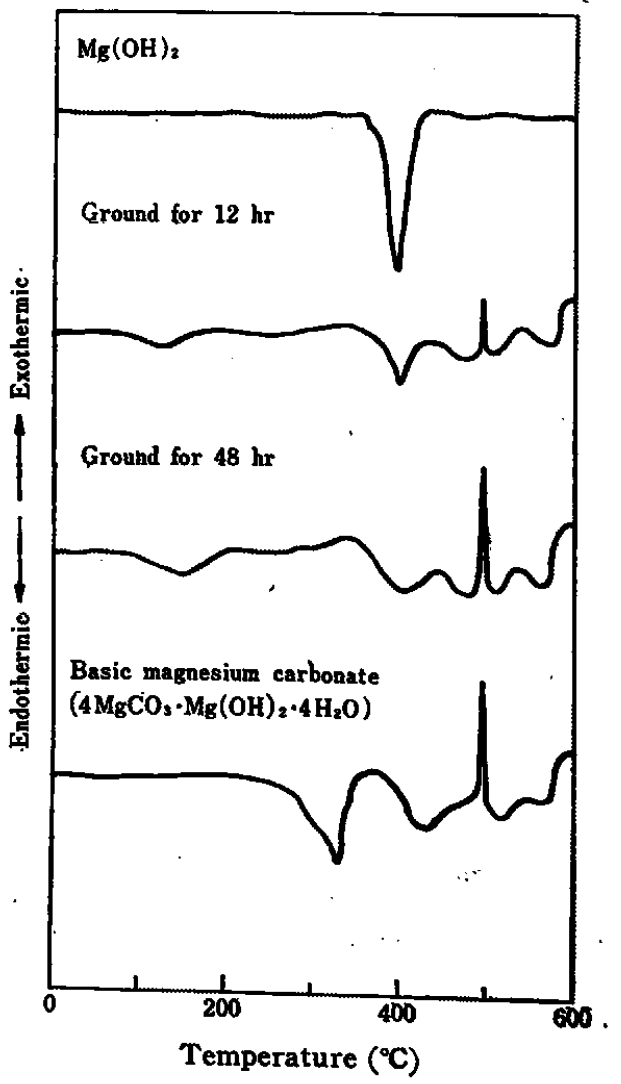

Fig. 6 DTA curves of $\mathrm{Mg}(\mathrm{OH})_{2}$, ground in air 
め, $\mathrm{Mg}(\mathrm{OH})_{2}$ のメカノケミカル分解の目的を達成することはで हない。

摩啸にとすな5 $\mathrm{Mg}(\mathrm{OH})_{2}$ のメカノケミカル脱水を確かめるた

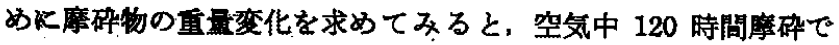
$164 \%, \mathrm{H}_{2} \mathrm{O}$ と $\mathrm{CO}_{2}$ をのぞいた空受中 142 時間噔碎で $5.3 \%$ と いずれる重量增加となった。摩砕過程の重量変化にはかなりのバ ラシキがみられたが，いずれの場合も重量減少を認めることはで きなかった。すなから，空気中の重量増加は塩基性炭酸マグネシ ウムへの変化によるるのであるが， $\mathrm{H}_{2} \mathrm{O}$ と $\mathrm{CO}_{2}$ をのぞいた空気 中でる $\mathrm{Mg}(\mathrm{OH})_{2}$ のメカノケミカル脱水を期待でさるような重量 減少は認められない。逆に重量増加がみられたことは，摩碎終了 後の試料の取り报い中に活性表面に服着する $\mathrm{H}_{2} \mathrm{O}, \mathrm{CO}_{2}$ の影響が さけられなかったためであろら。このようにして $\mathrm{H}_{2} \mathrm{O}, \mathrm{CO}_{2}$ を取

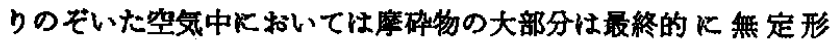
$\mathrm{Mg}(\mathrm{OH})_{2}$ としてとどる。以下，とくKことわらないがり空 気中摩碎とは $\mathrm{H}_{2} \mathrm{O} ， \mathrm{CO}_{2}$ を取りのぞいた空気中摩砕をさすことと し，ここで生成した無定形 $\mathrm{Mg}(\mathrm{OH})_{2}$ の諸性質を検討する。

空気中手砕におりる無定形化にとるならX線回折ピークの半価 幅增大から求めた $\mathrm{Mg}(\mathrm{OH})_{2}$ 各面の結晶子の大きさの変化性図 7 のとおりとなる。この場合の測定条件は図 5 と同じであるが， ニオメーターの走查条件は $0.5^{\circ} 2 \theta / \mathrm{min}$ とした。

図7によれば，摩砕にともなら細分化により，結晶子の大きさ はいちじるしく減少し 58 時間後には揤定の限界值に達し，その 啳恃X線的に無定形となる。

天野ら ${ }^{(6)}$ は $\mathrm{MgCl}_{\mathbf{2}}$ 溶液の電解によって得た $\mathrm{Mg}(\mathrm{OH})_{2}$ 結晶に ついて図8のよ5な模型的六方晶系を仮定し，結晶子の（001） 面，（110）面の厚及を測定し，その体稳を算出している。著者ら はこの方法によって求められた体積から麻碀物の比重を 2.39 と して重量を算出し, 表面積/重量から比表面積を求めた。結果は図 9 K示すとおりで, BET 法により求めた比表面積変化と比較す

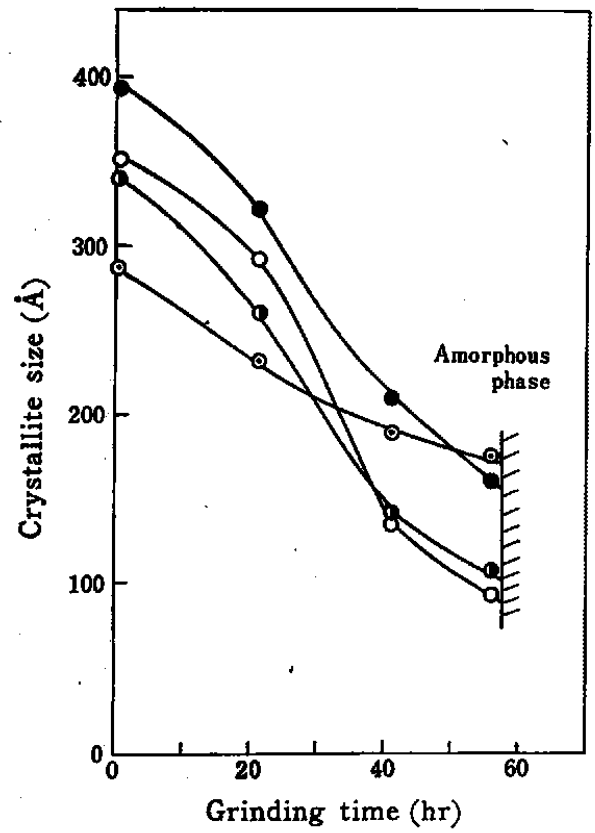

Fig. 7 Crystallite size of $\mathrm{Mg}(\mathrm{OH})_{2}$, ground in the air $O:(001), O:(110), O:(101), \odot:(111)$

16）天野一椎，岡，绞平，日本海水学会䄒，20，230(1967).



Fig. $8 D_{(h k l)}$ plane of hexagonal system

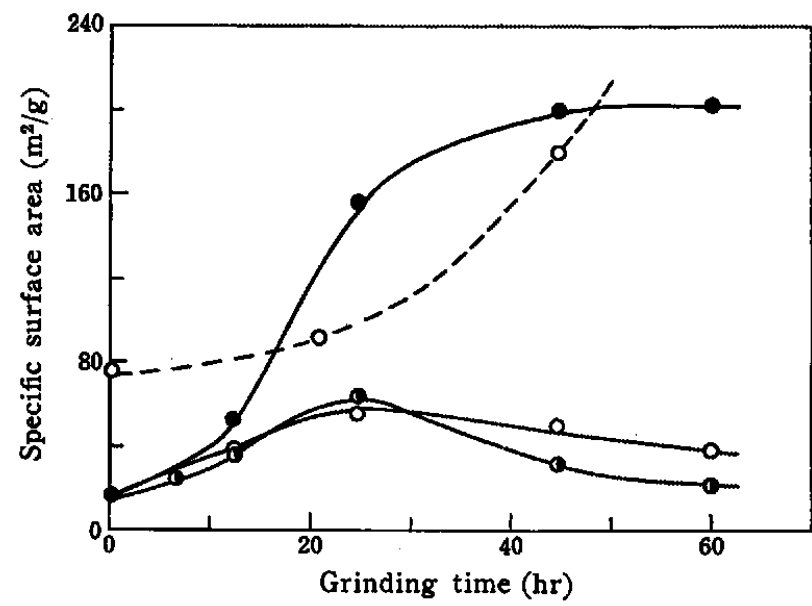

Fig. 9 Specific surface area of ground $\mathrm{Mg}(\mathrm{OH})_{2}$ 0 : in vacuum, $O$ : in air, $O:$ in the air (removed $\mathrm{H}_{2} \mathrm{O}$ and $\mathrm{CO}_{2}$ ), - measured by BET, - - : measured by $\mathrm{X}$-ray

るとかなり大きなひらきが認められる。橋詰ら 粒子KついてX線法括よび BET 法により比較し两者の值のよく 一致することを報じているが，この場合は粒子が単結晶に近い状 態にあるるのと考えられている。また，図 9によると空気中摩碎

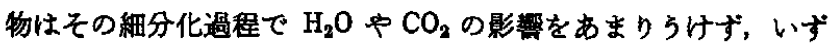
れも24 時間以後 2 次粒子の生成による比表面磧の低下をむたら すことがわかる。 $\mathrm{H}_{2} \mathrm{O}$ Ð $\mathrm{CO}_{2}$ の吸着は表面活性の中和に奇与す るあのと考えられるが，細分化がある程度進むと活性表面相互の 再結合の影盤の方が大きいのであろう。空気中摩碎物はこのよう にかなりの凝集性を示すが、アルコール中で高周波をかけて十分 分散させ，䉓子䫀酸鏡により観察すると，平均径 $0.15 \mu$ 程度の おおむね球状の粒子の集合体であることがわかる。15000 倍の写 真から単粒子として認めることがでさる粒子 200 個について計測 乙 ${ }^{18)}$ ，粒度分布曲線をつくると図 10 のとおりとなり，無定形相 である 58 時間摩砕物でみると $0.08 \sim 0.2 \mu$ の粒径の比較的そろ った状態にあることがわかった。

このよらにして得られた無定形 $\mathrm{Mg}(\mathrm{OH})_{2}$ の DTA 曲線を図 11 に示す。これによると OH 基の分解ピークの位置，大きさは 摩砕によってすはとんど変化せず，脱水にとすなら重量減少すみ られず，逆にわずかではあるが重量增加が認められたことから，

17）橋詰源藏, 網田佳代子，分析化学，19，667(1970).

18）粉体工学研究会編，“粉体粒度测定法”，裳紧(1970)p. 51 . 


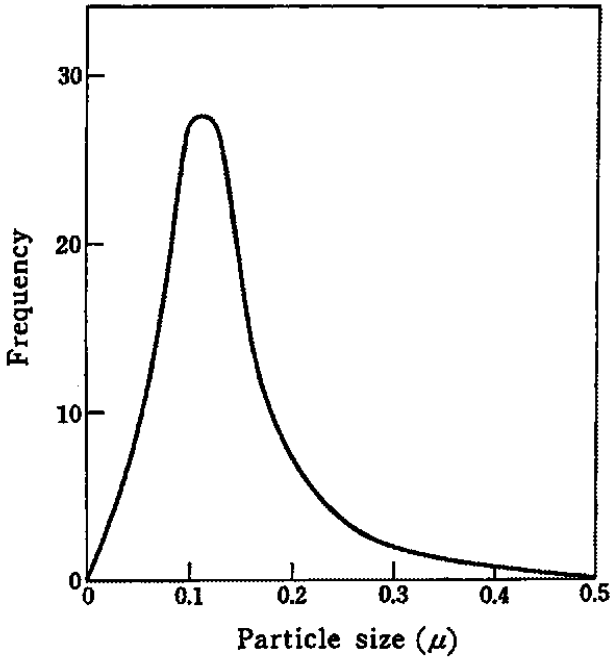

Fig. 10 Particle size distribution of $\mathrm{Mg}(\mathrm{OH})_{2}$, ground in the air

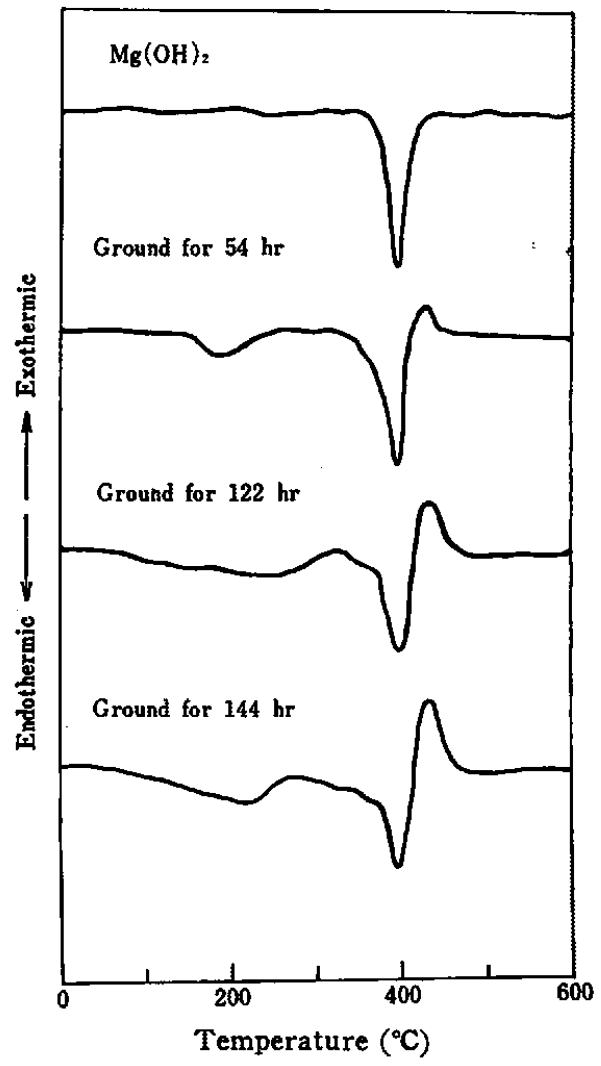

Fig. 11 DTA curves of $\mathrm{Mg}(\mathrm{OH})_{2}$, ground in the air $\mathrm{Mg}(\mathrm{OH})_{2}$ のメカノケミカル脱水は起こっていないとみるのが妥 当であろら。ただし，摩碎にとすなう $350^{\circ} \mathrm{C}$ 付近の吸熱ピークの 成長が咨問として残る。空気中摩砕物の DTA 曲線にみられる特 徽は $200^{\circ} \mathrm{C}$ 付近に拈ける層間吸着水の脱水とみられるゆるやかな 吸熱ピーク拈よび OH 基の分解直後に引きつついて起こる発熱ビ ークである。この発熱は無定形化後す摩砕時間ととすに増大して いるが，発熱直後の形態をX線回折により確がてみると，発熱

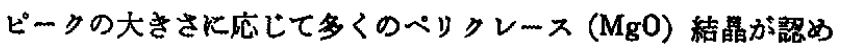
られる。すなわち，長時間摩破により格子不整の増大した $\mathrm{Mg}$ $(\mathrm{OH})_{2}$ が脱水を機に一挙に $\mathrm{MgO}$ の正規格子を形成するための 発熱であると推定された。これに対して $\mathrm{Mg}(\mathrm{OH})_{2}$ の加熱舩水過

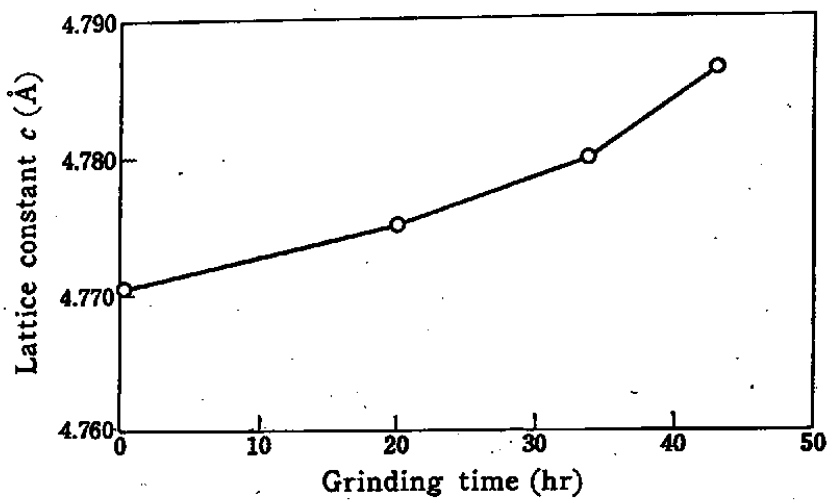

Fig. 12 Lattice constant of $\mathrm{Mg}(\mathrm{OH})_{2}$, ground in the air

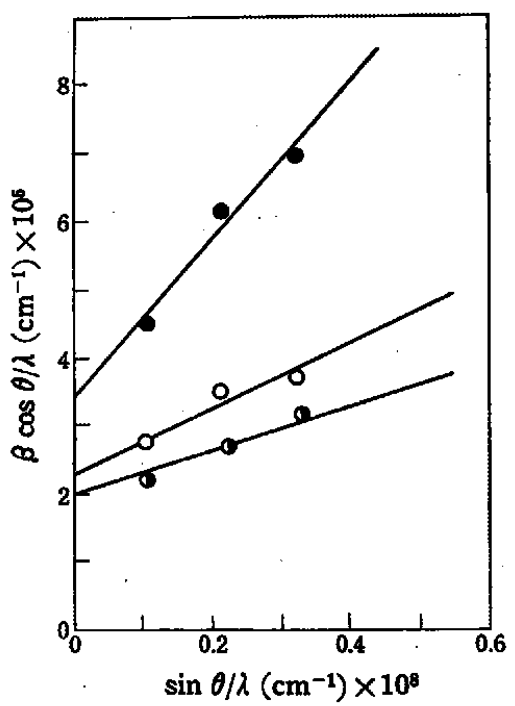

Fig. 13 Lattice distortion of $\mathrm{Mg}(\mathrm{OH})_{2}$, ground in the air O : $\mathrm{Mg}(\mathrm{OH})_{2}, \mathrm{O}: 24 \mathrm{hr}, \mathrm{O}: 41 \mathrm{hr}$

程では生成する $\mathrm{MgO}$ は $\mathrm{Mg}(\mathrm{OH})_{2}$ 母結晶の格子を保持し正規格 子をとるまでにはな括かなりの界温を必要とし ${ }^{19)}$ ，DTA 曲線に 括ける脱水と結晶化との時間的ずれが報ぜられている2 20)。

摩砕にとるなら $\mathrm{Mg}(\mathrm{OH})_{2}$ の格子定数 $c$ の变化を挤 $12 k$, 格 子不整の増大を図 13 飞示す。格子定数 $c$ 性石英を内部磦準とし て (001) ピークによって算出されたるので，摩䃏にとすない脚張 が認められ，4.786 $\AA$ 以上となるとるはやX継的に $\mathrm{Mg}(\mathrm{OH})_{2}$ と して圾認められなくなる。 $\mathrm{CdI}_{2}$ 型結晶粠造を有する $\mathrm{Mg}(\mathrm{OH})_{2}$ は $\mathrm{OH}^{-}$の六方密充テン周に $\mathrm{Mg}^{2+}$ 篔が 1 局おきにはいった棈成 をとり，陰イオンどらしが相接する OH-OH 硐は van der Waals 力Kよりつながるため（001）面はいちしるしいいキ開 性を有する。したがって摩碎㳊あたってる，この面よりの切䉼が 優先的に起こることが考えられ，その結果，表面に黑出したOHは新らしい表面エネルギー含量を低下させる工程として表面にお しでてくるであろ5。このような表面のイオン四貫の安定性を大 きくしよらとする動き，および䧻椎的エネルギーによる格子内と ズミの発生が $c$ 軸上の膨張となってあらわれたのであろう。一

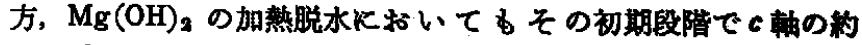
$0.02 \AA$ の一時的拡大が琶められているが、これは一部 $\mathrm{OH}$ 英の 脱水により OH 届の鱼菓荷が增すための反発作用であるといわ

19) P.J.Anderson, R.F.Horlock, Trans. Faraday Soc., 58, 1993 (1962).

20) C. N. R. Rao, K.S.Pitzer, J. Phys. Chem., 64, 282(1960). 
れている21)。

図 13 㤌 Hall 式 $\beta \cos \theta / \lambda=1 / \varepsilon+\eta \sin \theta / \lambda$ ( $\beta: X$ X線回折装置 固有の回折ビークのひろがりを差し引いた回折ピークの幅, $\lambda$ : $\mathrm{X}$ 線の波長 $(\dot{A}), \theta:$ 回折角 $\left({ }^{\circ}\right), \varepsilon$ : 結晶子の大きさ $(\dot{A}), \eta$ : 格子不整の比例値）飞怙いて, $\beta \cos \theta / \lambda$ と $\sin \theta / \lambda$ との関保を示 したもので11)， $\sin \theta$ の増加とともに $\beta \cos \theta$ が增加するならば 結晶は格子不整をもっていることとなり，その傾斜が格子不整の 大きさに相当する。摩碎とともに煩斜恃大となり, 格子不整の程 度も増していくようすが図 13 から確かめられる。58 時間以上は ピークの消隇により濆定はできなくなるが，X線的に無定形化し たのちる，格子不整怢引きつづき增大しているはずである。

\section{2 空中度砕}

空気中㗫碀により $\mathrm{Mg}(\mathrm{OH})_{2}$ 江究極的仁は見かけ上の平均粒径 任 $0.15 \mu$ 程度に微細化され，格子不整の增大よりX線的に完全 飞無定形相となるが，その有する $\mathrm{OH}$ 基はきわめて安定で，メカ ファミカル分解現象としてしばしば認められるよらなDTA 曲線 における分解ピークの低温度側への移動ははとんど認めることは できなかった。

そこで，つぎ超硬合金乳バチの設㯰してある密閉容器内を排 氮して $2 \times 10^{-2} \mathrm{mmHg}$ 程度の真空とし，このなかで $\mathrm{Mg}(\mathrm{OH})_{2}$ 結晶の摩碎を行なってみた。摩碎物のX線回折図形の変化を 15 〜65 $(2 \theta)$ の範围で示したのが図 14 で, 測定条件は図 5 の場合 とまったく同じである。

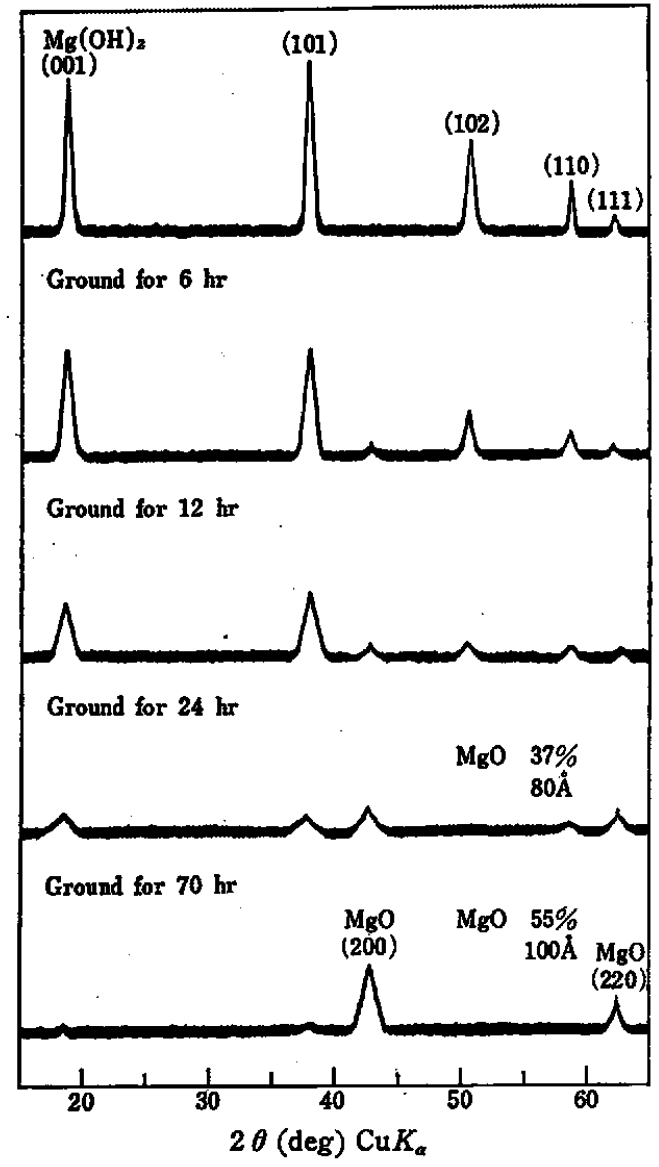

Fig. 14 X-ray diffraction patterns of $\mathrm{Mg}(\mathrm{OH})_{2}$, ground in vacuum $\left(10^{-2} \mathrm{mmHg}\right)$

21）浜野健也，密業協会誌，74，144(1966).
因 14 によると摩碎物は空気中摩碎と同じように $\mathrm{Mg}(\mathrm{OH})_{2}$ ビ 一クの消娍による無定形化の過程をとるが，その速度はすみやか で，空気中では 55〜60 時間で無定形化が達せられるのに対し， 30〜35 時間後飞怔 $\mathrm{Mg}(\mathrm{OH})_{2}$ の全ピークは消減する。しかも，そ

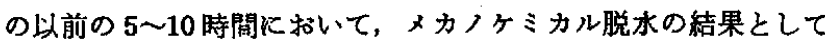
図形上にペリクレース結晶の生成がはっきりとあらわれはじめ, その量㹥摩碎時間とともに增大する。生成した $\mathrm{MgO}$ の量と結晶 子の大きさを X線回折ピークの面積および半価幅から求め, 図 14 のX線回折图形化あわせ示した。な拉，Mg0 の定量化ついては メカノケミカル处理物の場合，格子不整によるラインブローディ ングの影響が大きいため，定量値が過大に算出するおそれがあ る。そこで，本報では $\mathrm{Mg}(\mathrm{OH})_{2}$ の加熱脱水過程で生ずる同程度 の結晶子の大きさを有する $\mathrm{MgO}$ を標洀物質としてえらび半定量 を試みた。たと党ば $\mathrm{Mg}(\mathrm{OH})_{2}$ を $450^{\circ} \mathrm{C} て ゙ 30$ 分加熱して得られ る $\mathrm{MgO}$ の結晶子の大きさは $70 \AA$ である。摩碎伙とすない $\mathrm{MgO}$ の生成量は增大し，一方，結晶子の大きさの変化から結晶成長が 認められるが，摩碎 70 時間後の $\mathrm{MgO}$ 生成量は約 $55 \%$ 程度， その結晶子の大きさは $100 \AA$ 程度で，その後比表面積の增加がゆ るやか炕なると，大きな変化はみられなくなる。この場合，微細

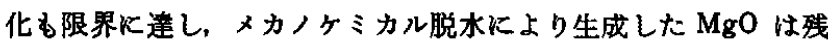
存する無定形 $\mathrm{Mg}(\mathrm{OH})_{2}$ とメカノケミカル平衡達したすのとみ なされる。

摩碎物の重量変化を求めてみると，最高 $4.5 \%$ の重量减少から 最高 2.3\%の重盡增加の間をデータはばらついて括り，摩碀時間 とメカノケミカル脱水量との間のはっきりとした関係㹥されな かった。これは摩碎中はつねにロータリーポンブを作動して 10-2 $\mathrm{mmHg}$ のレペルは保持しているものの，わずかの空気柱容器内 に侵入して摩硪物に接しては排除されているわけで $\mathrm{H}_{2} \mathrm{O}, \mathrm{CO}_{2}$ の 吸着による增量がさけられないこと，したがって真空度もわずか ではあるが変動して括り，脱水量の多少はこの変動にきわめて鋭 敏であることなどの理由があげられよう。

真空中比拈ける $\mathrm{Mg}(\mathrm{OH})_{2}$ のメカノケミカル脱办についてさら 飞考察されることは，摩碀炕ともなら此表面積の増加と，これに ともない表面に露出されてくる $\mathrm{OH}$ 層の真空中に战ける安定性で ある。乙加し，空気中摩碎似よって比表面積か $60 \mathrm{~m}^{2} / \mathrm{g}$ 程度微 細化された無定形 $\mathrm{Mg}(\mathrm{OH})_{2}$ を, 真空摩碎中はつねに同一容器内 飞併置してその脱水の有無を検討したか，その DTA 曹線怯まっ たく変化はみられず，機械的エネルギーが加えられていない状態 飞おいてはその有する $\mathrm{OH}$ 基㹥安定であり, 逆に表面の清浄化に よる結晶の成長がみられる。したがって，その他炕考兄られるこ とはズり応力により格子のみだれた表面に括いて，真空中では構 造欠宿を利用して OH 基の拡散移動が行なわれやすく，相互の接 触化よる脱水が行なわれる可能性もある。

$$
\mathrm{OH}^{-}+\mathrm{OH}^{-} \longrightarrow \mathrm{O}^{2-}+\mathrm{H}_{2} \mathrm{O}
$$

あるいはプロトンが $\mathrm{OH}$ 基からはなれて他の $\mathrm{OH}$ 基と結合して $\mathrm{H}_{2} \mathrm{O}$ 分子となる可能性むある。

$$
\begin{aligned}
& \mathrm{OH}^{-} \longrightarrow \mathrm{H}^{+}+\mathrm{O}^{2-} \\
& \mathrm{H}^{+}+\mathrm{OH}^{-} \longrightarrow \mathrm{H}_{2} \mathrm{O}
\end{aligned}
$$

いずれにせよ，母結晶である $\mathrm{Mg}(\mathrm{OH})_{2}$ の $\mathrm{OH}^{-}$層とその脱水物 である $\mathrm{MgO}$ の 02- イオンと悦水のさい，大きな変位を必要 としない利点がある。すなわち, 図 15 は $\mathrm{Mg}(\mathrm{OH})_{2}$ と $\mathrm{MgO}$ と の配位関係を示したものであるが，六方晶系の $\mathrm{Mg}(\mathrm{OH})_{2}$ に猢 


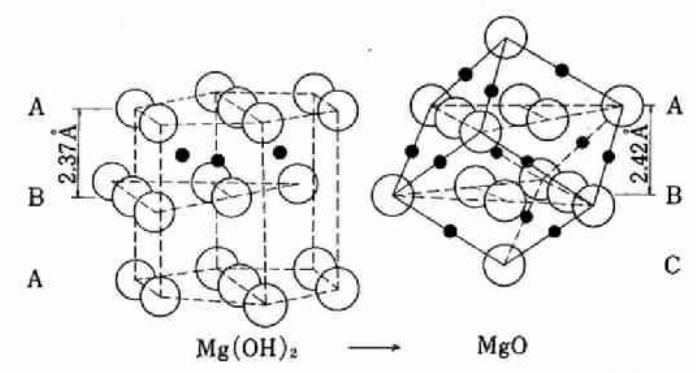

Fig. 15 Topotactic dehydration of $\mathrm{Mg}(\mathrm{OH})_{2}$

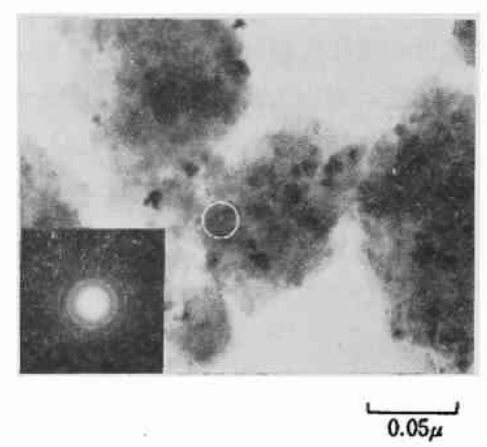

Fig. 16 Electron microscopic observation and electron diffraction (field limiting aperture) of $\mathrm{Mg}(\mathrm{OH})_{2}$, ground in vacuum

る $\mathrm{OH}$ 基の六方最密充テン層はそのまま立方晶系の $\mathrm{O}^{2-}$ イオン

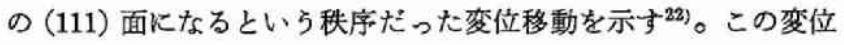
は空気中では達せられず，真空中に柿いて $\mathrm{OH}$ 基の安定性低下に よってはじめて可能となる。

真空中摩碎物の比表面積変化を BET 法により求めて図 9 に示 し, 空気中摩砕物のそれと比較した。これによると空気中摩砕と くらべ比表面積の增加はいちじるしく，摩砝 40〜50 時間で 200 $\mathrm{m}^{2} / \mathrm{g}$ となり, その後は平衡に達する。媒体中での摩砕は媒体分 子が粒子間の潤滑性を高め，したがって真空中では帯電のため摩 研効果が低下するといら知見 ${ }^{23)}$ があるが，本報ではこのように結 果がまったく逆となった。たしかに真空中で生成した粒子表面の 活性は大きく粒子の見かけ上の凝集ははっきり認められるが，電 子䫒微鏡でみると単独粒子の大きさは空気中摩砕物のそれよりむ いちじるしく小さい。このよらに真空摩砕物は凝集しやすい性質 を有するにもかかわらず钽細化し，図 14 でみられると括り無定 形化もすみやかであることは，空気中での無定形化は微細化と庆 力にともなら格子内ひずみの発生に起因するのに対し，真空中て の钽細化，無定形化はもっぱらメカノケミカル脱水にともなら格 子の再配列に起因するものと思われる。

真空中摩砕物 90 時間の電子顕微鏡観察を図 16 に示す。これ は 300000 倍の倍率であるが，径 0.08 0.1 $\mu$ 程度の粒子の集合 体からなり，その大きさ，形状は空気中摩群物の場合とくらべる とかなり小さい。注目すべきことは，粒子内部にはっきりと密度 の異なる黑点が散在して抽りこれらは $\mathrm{MgO}$ 結晶とみられそ の大きさ $0.015 \mu$ は結晶子の大きさ $100 \AA$ とほぼ一致する。図 16 には電子線回折図るかかげたが，ハン点状のリングがはっき りとあらわれてきて特り，摩砕物はX線的に無定形であるにあか かわらず，異方性の大きい結晶がまた残存していることを示す。

真空中摩碎物の DTA 曲線を図 17 に示す。 $\mathrm{Mg}(\mathrm{OH})_{2}$ の $\mathrm{OH}$ 基の脱水ピークは摩砕にともないすみやかに消減するが，一方，

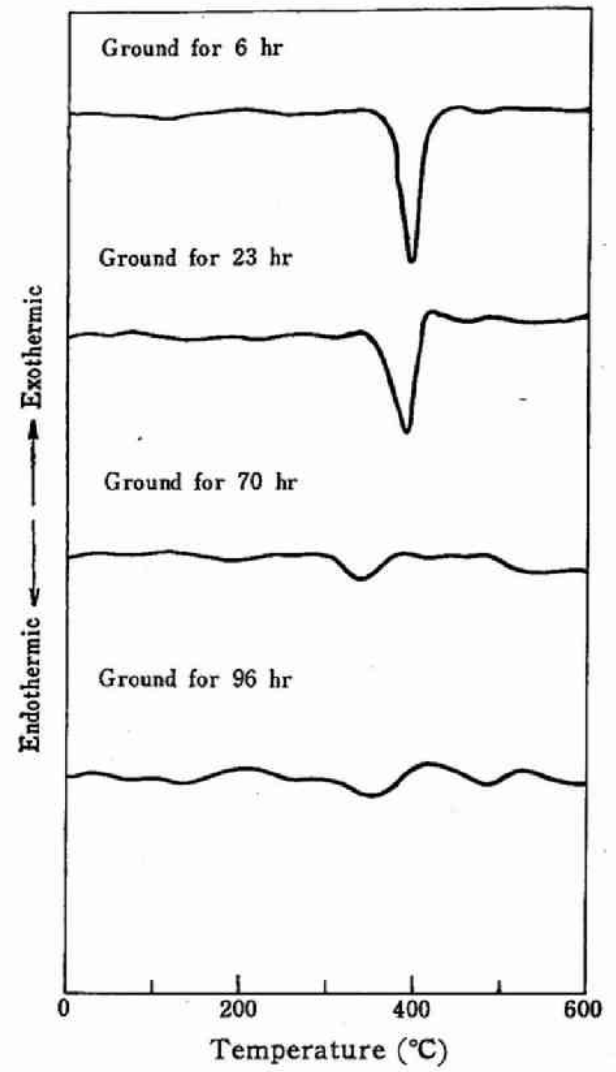

Fig. 17 DTA curves of $\mathrm{Mg}(\mathrm{OH})_{2}$, ground in vacuum

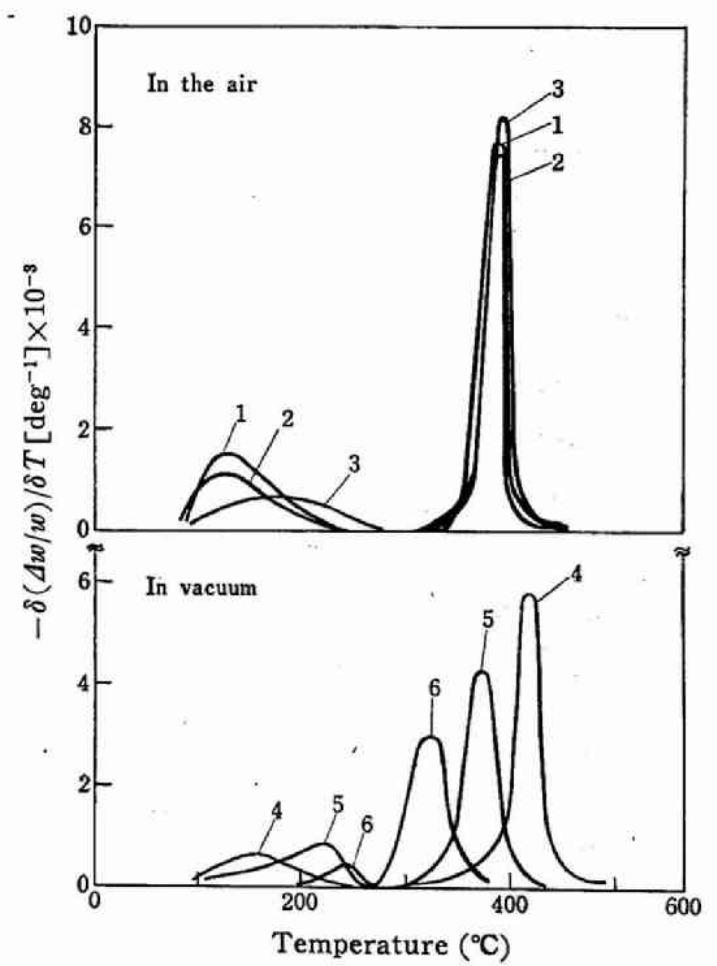

Fig. 18 TGA curves of ground $\mathrm{Mg}(\mathrm{OH})_{2}$ (plot of $-\delta(\Delta w / w) / \delta T$ against temperature)

Grinding time

(1) $: 54 \mathrm{hr},(2): 67 \mathrm{hr},(3): 122 \mathrm{hr}$

(4) $: 6 \mathrm{hr},(5): 23 \mathrm{hr}$, (6) $: 70 \mathrm{hr}$

22） G.W. Brindley, 墨業協会誌, 69, 189(1961).

23）神保元二, “粉体の物性と工学”, 化学同人(1967)p. 270. 
$400 \sim 600^{\circ} \mathrm{C}$ の範囲に䒇広い発熱があらわれる。これは繁砕中に 吸着または反応した $\mathrm{CO}_{2}$ の影響と考える。すなわち，图6の堭 基性炭酸マグネシウムの DTA 曲線をみると, $500^{\circ} \mathrm{C}$ 付近にシャ ープな発熱がある。

図 18 に加熱にとすな5摩砕物の重量減少の変化率曲線を示し た。これはDTA 曲線と同時測定した熱重量分析曲線を $20^{\circ} \mathrm{C}$ 間


きらかとなる。空気中で庶碎した埸合，X線的に無定形化するは ど微細化と格子の変形は進行するが，その有する $\mathrm{OH}$ 基は安定 で、メカノケミカル変化の一般現象としてみられるような脱水温 度の低温度側への移鋤 ${ }^{113}$ は汪とんど認められない。しかし，真空 中で摩挽した场合は重量变化率のピークは图 18 でみられるよう にはっきりと低温度側入移動している。なお， $100 〜 300^{\circ} \mathrm{C}$ 間に おける減量は罪間吸着水の脱水である。

\section{3 能破物の蓄面活性}

$\mathrm{Mg}(\mathrm{OH})_{2}$ 結晶塩基性塩の性筫として, 空気中の $\mathrm{CO}_{2}$ のよ5 な醉性成分から影策をらけやすいが，その影響の程度は接触する 湿分の多少により鋭敏伙作用する。麻砕にともない樶着に有效な 表面耫は急增し，さらにその表面は化学結合の切断により奄気的 中性を失い、ズり忘力により格子がひずんでくるためかなりの高 エネルギー状態となり，活性にとんだ状態となる。

图 19 は摩砕物の赤外吸収スペクトル曲線を示し、 $\mathrm{H}_{2} \mathrm{O}, \mathrm{CO}_{2}$ の影管を対比したるのである。廉碎化より $1380 \mathrm{~cm}^{-1}$ の $\mathrm{Mg}(\mathrm{OH})_{2}$ 結晶の特性吸収波恃消娍し, $2800 \sim 3700 \mathrm{~cm}^{-1}$ および 1300 1450 $\mathrm{cm}^{-1}$ の 2 簓所にかなり楅広い吸収が成带する。前者は眼着水 ${ }^{11)}$ ， 後者は $\mathrm{CO}_{8}^{2-24)}$ の影鳘である。なお, $\mathrm{Mg}(\mathrm{OH})_{2}$ 試料にみられる $3800 \mathrm{~cm}^{-1}$ の鋭い昅取は付着水である。このように摩砕物は空気，

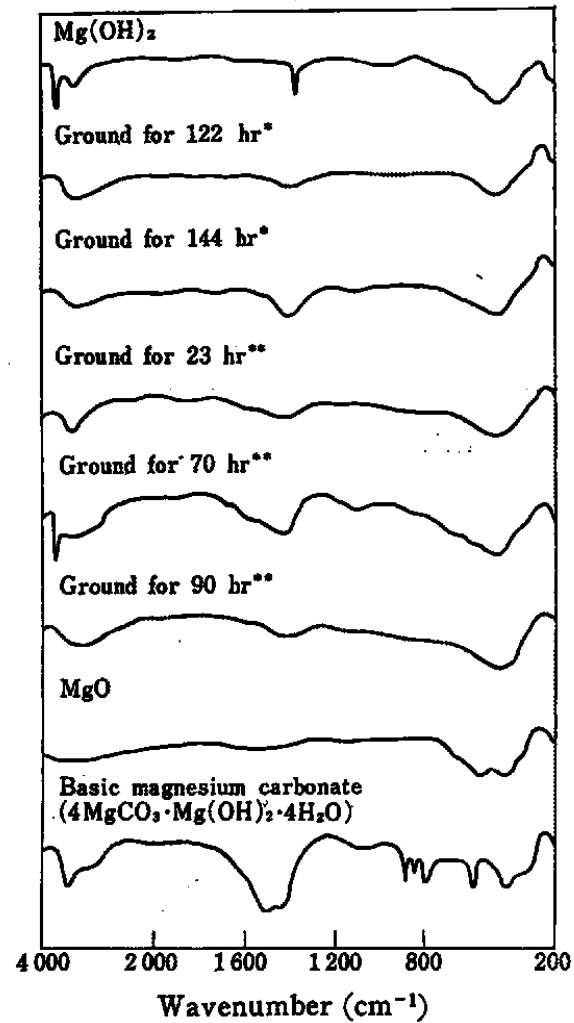

Fig. 19 Infrared spectra of ground $\mathrm{Mg}(\mathrm{OH})_{2}$ *: in the air, **: in vacuum
中より $\mathrm{H}_{2} \mathrm{O}, \mathrm{CO}_{2}$ をのぞいてもあるい悾気をのぞいて真空中 としても，長時間慗砕では完全に取りのぞけぬ知量の $\mathrm{H}_{2} \mathrm{O}, \mathrm{CO}_{2}$ が摩砕物の活性表面に涱穕されることとなる。

このように摩砕物表面はかなりの活性を有することが確かめら れたが，摩确にともなら活性の発生過程を摩碎物の塩基性点の数 （塩基度といら）から求めてみた。すでK述べたように，塩基性 点の構造についてはまだ十分な研究が行なわれていなが，脱水し た $\mathrm{MgO}$ の表面には吸着中に $\mathrm{CO}_{3}{ }^{2-}$ に変えられる強い塩基性点 $\mathrm{O}^{2-}$, 表面 $\mathrm{OH}$ 基ととなりあった強い㙁基性点 $\mathrm{O}^{2-}$, 弱い塩基性 点 $\mathrm{OH}^{-}$の 3 敇があると考えられている ${ }^{19)} 。 \mathrm{Mg}(\mathrm{OH})_{2}$ 結晶の加 熱にともなら㷪基度の変化を追跡してみると図20のようになり， 脱水直後の $400^{\circ} \mathrm{C}$ 付近において最高值に達し以後すみやかに低下 する。すなわち，水酸化物が脱水しながら $\mathrm{MgO}$ 正規格子を形成 するためのイオンの移動，再配列が行なわれている間は，まだ 結晶の骨格をそのまま残した構造不整の大きい $\mathrm{MgO} キ ゙$ 結晶が生

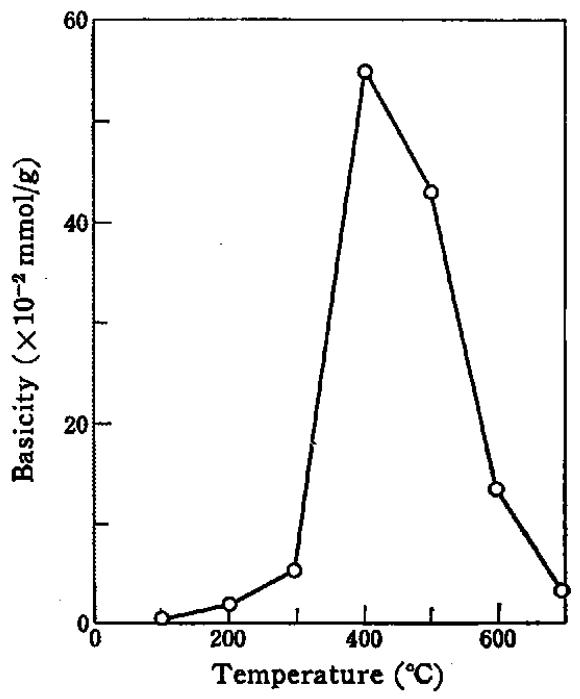

Fig. 20 Basicity of calcined $\mathrm{Mg}(\mathrm{OH})_{2}$

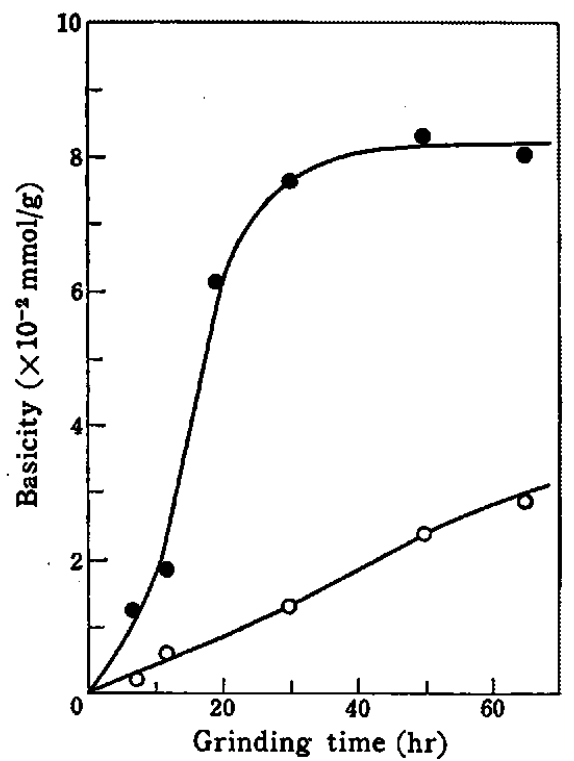

Fig. 21 Basicity of ground $\mathrm{Mg}(\mathrm{OH})_{2}$ : in vacuum, $O:$ in the air

24) K. Nakamoto, “Infrared Spectra of Inorganic Coordination Compounds", John Wiley \& Sons (1970)p. 98 
成するはずでありこの過程において上記 3 種の塩基性点が発生 することは明らかである。さらに温度が上がり $\mathrm{MgO}$ が正規格子 をとるにつれて塩基性点の数は急減していく。

これに対して摩砕物の塩基度変化を図 21 に示す。真空中摩砕 物の塩基度もメカノケミカル脱水による $\mathrm{MgO}$ ギ結晶の生成に起 因するものであるが，その生成量は少ないため加熱物の塩基度に およばない。しかし， MgO の生成量が限界に達したのちはほと んど一定值をたもち低下することはない。すなわら, メカノケミ カル脱水によって生じた $\mathrm{MgO}$ ギ格子の正規格子への回復はおそ く, 摩砕 70 時間後に生成した $\mathrm{MgO}$ の格子定数 $a=4.2368 \AA$ で, ペリクレースの格子定数 $a=4.2120 \AA$ とくらへかなり大きい。

空気中摩砕物の塩基度は構造不整の大きい無定形 $\mathrm{Mg}(\mathrm{OH})_{2}$ の みだれた $\mathrm{OH}$ 基層に起因するもので, $\mathrm{OH}^{-}$の不均一分布, $\mathrm{O}^{2-}$ に $\mathrm{CO}_{2}$ を強く吸着した $\mathrm{CO}_{3}{ }^{2-}$ の影響も無視できないものと考え る。すなわち, $\mathrm{Mg}(\mathrm{OH})_{2}$ はまったく塩基度を示さないが，塩基 性炭酸マグネシウムは一般に低結晶性ではっきりと塩基性点があ らわれる。

真空摩砕物の表面状態を電子頭徽鏡で観察したのが図 22 で, 左図は 3000 倍の倍率でみたもので, 微小粒子の频集物であるが, その 1 部を 30000 倍に払大してみると右図のとおりとなり, 表面 状態がよくわかる。すなわち，摩砕物表面は 0.04 0.15 $\mu$ の層 状粒子が積み重なった状態にあり，X線的に無定形化するまで破 壊され，脱水物 $\mathrm{MgO}$ もかなりの量が生成しているにすかかわら ず, 外観状は母結晶である $\mathrm{Mg}(\mathrm{OH})_{2}$.の層状構造がそのまま残っ ているのを認めることができる。空気中摩砕物の表面状態も図 22 と大きな相違はない。

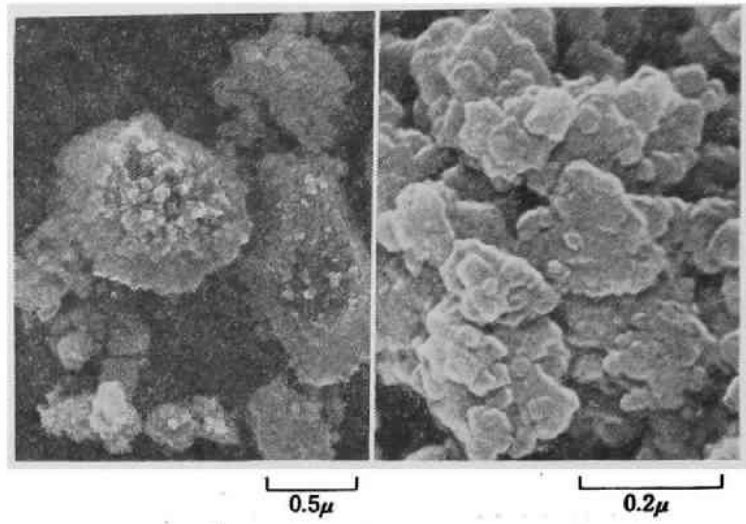

Fig. 22 Scanning electron microscopic observation of $\mathrm{Mg}(\mathrm{OH})_{2}$ surface, ground in vacuum

$\mathrm{Mg}(\mathrm{OH})_{2}$ 結晶を空気中で摩砕するとき, 影響力の大きい $\mathrm{H}_{2} \mathrm{O}$ や $\mathrm{CO}_{2}$ をとりのぞいても，粒子間の凝集によりその微細化には 限界があり，摩砕物の不整化はかなり進行しているにすかかわら ず $\mathrm{OH}$ 基は安定でメカノケミカル脱水を認めることはできなかっ た。しかし, 真空中で摩碎すると微細化の限界は向上し, メカノ ケミカル脱水が起こって MgO に転移することが明らかとなっ た。その脱水速度を支配するものは摩磱物の表面積の大きさ，構 造不整の程度および真空度の多少で, これらが相互に影翋をおよ ぼしながら摩砕物表面の $\mathrm{OH}$ 基の拡散に寄与しているすのと思わ れる。

本報告の実験は日本大学理工学部学生, 滝口治義君, 山口 勇 君の熱心なる協力のるとに行なわれたことを付記し感謝の意を表 ナる。

\title{
Mechanochemical Phenomena of Magnesium Hydroxide by Grinding ${ }^{\dagger}$
}

\author{
Yasuo Arai, Tamotsu Yasue and Hisatoshi Miyake \\ Department of Industrial Chemistry, Faculty of Science and Engineering, \\ Nihon University ; Kanda-Surugadai, Chiyoda-ku, Tokyo, Japan
}

Studies were made to investigate fine dividing and structural change of $\mathrm{Mg}(\mathrm{OH})_{2}$ crystal during grinding as an example of mechanochemical dehydration of hydrate crystals. The mortar of super hard alloy (WC-Co system) was especially used instead of agate mortar to avoid the reaction with silica for grinding.

In the case of grinding in air, $\mathrm{Mg}(\mathrm{OH})_{2}$ was rapidly converted into amorphous phase indicated by X-ray and its weight increased considerably with time under the influence of $\mathrm{H}_{2} \mathrm{O}$ and $\mathrm{CO}_{2}$. The differential thermal analysis (DTA) curve of the ground material after 48 hours was quite similar to that of basic magnesium carbohate reported as $4 \mathrm{MgCO}_{3} \cdot \mathrm{Mg}(\mathrm{OH})_{2} \cdot 4 \mathrm{H}_{2} \mathrm{O}$. In the case of grinding in the air removed $\mathrm{H}_{2} \mathrm{O}$ and $\mathrm{CO}_{2}, \mathrm{Mg}(\mathrm{OH})_{2}$ also became amorphous phase but no mechanochemical dehydration was found from the weight change. In the DTA curve of amorphous $\mathrm{Mg}(\mathrm{OH})_{2}$, a sharp characteristic exothermic peak appeared immediately after decomposition of the hydroxide due to recrystallization of $\mathrm{MgO}$. In both cases, specific surface area of the ground materials approached to a maximum $\left(60 \mathrm{~m}^{2} / \mathrm{g}\right)$ but gradually decreased after 24 hours by the formation of secondary particle.

In the case of grinding in vacuum $\left(10^{-2} \mathrm{mmHg}\right), \mathrm{MgO}$ crystal was clearly found after 24 hours as the results of mechanochemical dehydration with rapid conversion of the hydroxide into amorphous phase and the amount rised up to $55 \%$ after 70 hours. With approaching to the limit of size reduction by grinding, the distorted and expanded crystal of $\mathrm{MgO}$ (lattice constant $4.2368 \AA$, crystallite size $100 \AA$ ) should be mechanochemically equilibrated with amorphous $\mathrm{Mg}(\mathrm{OH})_{2}$. In this case, the specific surface area became much larger than that of air grinding $\left(200 \mathrm{~m}^{2} / \mathrm{g}\right.$ after 70 hours). Surface activity of ground materials were discussed from the number of basic points.

$\uparrow$ Studies on Mechanochemical Phenomena of Hydroxide. I. 